of CXCL16, an inflammatory signalling molecule linked to the T cells, was also elevated in the lungs and colon, and seemed to be regulated by microbes.

Mice exposed to microbes as neonates, but not as adults, showed a decreased accumulation of the T cells, emphasizing the importance of early exposure.

Science http://dx.doi.org/ 10.1126/science.1219328 (2012)

For a longer story on this research, see go.nature.com/ hacoqo

\section{REGENERATIVE BIOLOG}

\section{Cell transplants repair colon}

Tissue derived from gut stem cells can repair intestinal damage when transplanted into mice.

Mamoru Watanabe at the Tokyo Medical and Dental University, Hans Clevers at the Hubrecht Institute and University Medical Centre in Utrecht, the Netherlands, and their colleagues cultured intestinal fragments from mice and transplanted the cells, which included colonic stem cells, into mice with acute colitis. These mice gained more weight than untreated mice during the first week after treatment, and four weeks after transplantation the repaired intestinal lining seemed to be identical to the surrounding native tissue.

Colonic tissue grown from a single stem cell and placed in the mouse gut also regenerated the lining. Culturing colonic tissue from stem cells could be a therapeutic approach for human intestinal disorders such as colitis, the authors say. Nature Med. http://dx.doi. org/10.1038/nm.2695 (2012)

\section{PLANETARY SCIENCE}

\section{What lies beneath Mercury's surface}

After its first year in orbit around Mercury, NASA's MESSENGER spacecraft has yielded data on the planet's structure: the iron core is larger than previously thought and, unusually, is encased in a relatively thin shell of iron sulphide.

Maria Zuber at the

Massachusetts Institute of Technology in Cambridge and her colleagues built a gravity model for the planet using measurements of tiny changes in the spacecraft's orbit. Combining this model with data on the planet's topography and spin, the authors found that as much as $85 \%$ of Mercury's radius is taken up by its dense iron core. This, along with the iron sulphide shell, helps to explain the planet's gravity field.

Another paper from Zuber and colleagues suggests that volcanic and tectonic activity persisted well past Mercury's first several hundred million years. This could explain surface features observed by the team, such as uplifted or tilted basin floors.

Science http://dx.doi. org/10.1126/science.1218809; http://dx.doi.org/10.1126/ science.1218805 (2012) For a longer story on this research, see go.nature.com/ orseqg

\section{METABOLISM}

\section{Gain neurons, gain weight}

Mice consuming a high-fat diet generate new neurons in a part of the brain that controls feeding and metabolism. These cells may, in turn, promote the accumulation of fat.

Seth Blackshaw at Johns Hopkins University in Baltimore, Maryland, and his colleagues found a region of brain-cell production in the hypothalamus - which regulates eating and energy use - in young adult mice. Animals fed a high-fat diet had four times the rate of neuronal production in this region, called the median eminence, than those on a normal diet.

When this brain-cell generation was blocked, mice on the fatty diet gained less weight and exhibited a

COMMUNITY CHOICE

The most viewed papers in science

\title{
Tracking Taz's transmissible cancer
}

\section{HIGHLY READ \\ on www.cell.com 20 Feb-21 Mar}

The contagious facial cancer devastating populations of the endangered Tasmanian devil in Australia probably originated from a female animal, a genomic analysis finds.

Elizabeth Murchison and Michael Stratton at the Wellcome Trust Sanger Institute in Hinxton, UK, and their colleagues sequenced the genomes of two healthy Tasmanian devils and two geographically distinct tumours derived from the cancer, which is spread through biting. They also analysed the genomes of 104 other tumours from across Tasmania and found that the original tumour has evolved into different subclones. Six devils had tumours with two different genetic profiles, suggesting that exposure to the cancer does not protect the animals against future bites. Cell 148, 780-791 (2012)

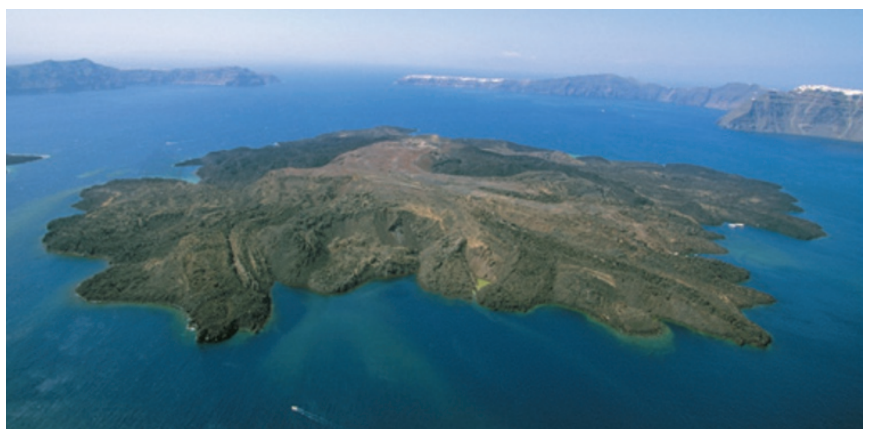

speedier metabolism than animals that ate the same diet and continued to produce new neurons.

Nature Neurosci. http://dx.doi. org/10.1038/nn.3079 (2012)

\section{GEOPHYSICS}

\section{The reawakening of Santorini}

After 60 years of silence, the volcano that erupted to form the Greek islands of Santorini (pictured) thousands of years ago seems to have reawakened.

Andrew Newman at the Georgia Institute of Technology in Atlanta and his colleagues analysed data from 24 Global Positioning System stations around the volcano from 2006 to 2012. They found that, since the beginning of 2011, the volcano's main caldera, a crater-like depression, has been expanding by up to 18 centimetres in diameter per year - probably as a result of the expansion of its source of magma, some four kilometres below the surface. The ground deformation coincided with observations of renewed seismic activity in the area.

The earthquake activity and ground deformation could be a prelude to a small eruption, the researchers say, but a mega-eruption is unlikely. However, other volcanoes of the same type that have shown similar signs of unrest have returned to normal activity without erupting at all. Geophys. Res. Lett. http://dx.doi. org/10.1029/2012GL051286 (2012)

\section{DNATURE,COM}

For the latest research published by Naturevisit:

www.nature.com/latestresearch 